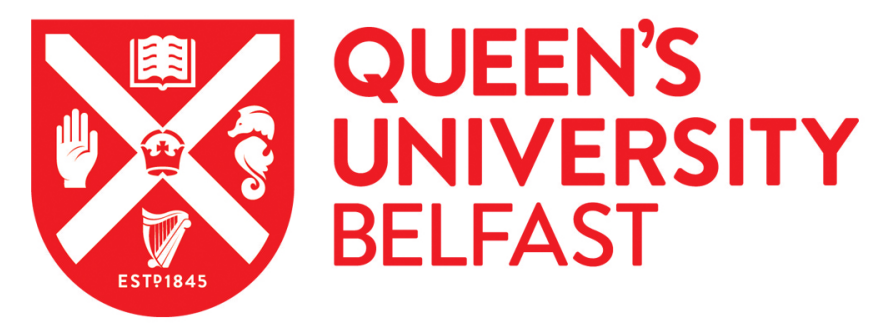

\title{
The whisperings of ghosts: Loss, longing, and the return in Stolen Generations stories
}

Murphy, F. (2018). The whisperings of ghosts: Loss, longing, and the return in Stolen Generations stories. Australian Journal of Anthropology, 29(3), 332. https://doi.org/10.1111/taja.12294

Published in:

Australian Journal of Anthropology

Document Version:

Peer reviewed version

Queen's University Belfast - Research Portal:

Link to publication record in Queen's University Belfast Research Portal

Publisher rights

Copyright 2018 Wiley. This work is made available online in accordance with the publisher's policies. Please refer to any applicable terms of use of the publisher.

\section{General rights}

Copyright for the publications made accessible via the Queen's University Belfast Research Portal is retained by the author(s) and / or other copyright owners and it is a condition of accessing these publications that users recognise and abide by the legal requirements associated with these rights.

Take down policy

The Research Portal is Queen's institutional repository that provides access to Queen's research output. Every effort has been made to ensure that content in the Research Portal does not infringe any person's rights, or applicable UK laws. If you discover content in the Research Portal that you believe breaches copyright or violates any law, please contact openaccess@qub.ac.uk. 
Title: The Whisperings of Ghosts: Loss, Longing, and the Return in Stolen Generations Stories.

\author{
Dr. Fiona Murphy, The Senator George J. Mitchell Institute for \\ Global Peace, Security, and Justice, Queen's University Belfast. \\ Northern Ireland.
}

\begin{abstract}
This article examines the telling of ghost stories of Indigenous Australians who were removed from their families during Australia's assimilation era. Known as the Stolen Generations, this group of people, were subjected to institutionalisation, adoption, and forced removals from their families, communities and Aboriginal country. In many of my ethnographic encounters with Stolen Generations, I was steadily drawn into their world of ghosts and hauntings. This article reflects on the challenge for the ethnographer in thinking with and through such encounters with the uncanny. It asks how we should approach the ghost as a real entity as well as a metaphorical, interpretative lens through which to understand the transgenerational trauma and suffering inflicted by settler colonial violences.
\end{abstract}

Keywords: Stolen Generations, Indigenous Australia, Uncanny, Ghosts, Haunting, Ethnography

\title{
Introduction: Conversing with the Ghostly
}

"Tell her the story about the hand."

"No, I cannot, hush, hush. That is only for us."

"No, tell her, please, it is alright, she is a good one."

Two sisters are arguing in front of me and some of their Stolen Generation friends. We are gathered together at the site of a former institution for Aboriginal children drinking coffee, and eating light, crumbling fairy cakes. "It is ok, really, if Vera does not want to tell me, then that is fine." I smile, wandering off for a minute, camera in tow. Click, snap, click. The sisters continue to argue. I hear snippets about secrets, and ghosts, hauntings and protection. I wander back to the group, fearing my precious coffee will cool. "She is going to share with you - the story of the hand." Smiles circle around me as we sit on the grass. The women become little girls again as the rapture and giddiness becomes contagious. "Hush, hush. If Vera is to share this story again, we must listen carefully." "Hush, hush. It used to come at night." The other girls nod in agreement. "It used to creep across our beds, the hand. Grab us, choke us, hurt us, the hand." I stare across the rusted hills. The image of little girls alone in a cold, loathsome dormitory is all I can focus on. They tell me how they used to snuggle together, three or four to a bed, to keep warm, and to ward off the 
phantoms of the night. The image of the hand circles around us. Fear replaces laughter and smiles are drowned by anxious sighs. We sit in the sun with the memories of long lonely nights floating above us.

Fieldnote diary

The 'story of the hand' conjures a fearful image of ghostly night-time comings and goings in an institution for Indigenous Australian children removed from their families and communities (Stolen Generations). I first heard the story of the hand when travelling with a number of Aboriginal women to the institution where they had spent a good proportion of their childhood. Together with the women, I spent the day visiting significant sites from their childhood memories, ending finally with a visit to the institution itself, now functioning as a bible college (Murphy 2012). Having spent the day attending reconciliation meetings and visiting sites of importance, we moved around the institution with the women pointing to sites of deep affect and significance; such as a well, a tree under which they would sit and dream about their mothers, and then to the space where their dormitory once stood. In the intensity of this return to this complex place, an institution that was at once home and a site of trauma, the story of hand was told to me. It continues to linger, even haunt my relationship as an anthropologist to a field-site beleaguered with the complexities of trauma and suffering.

In this article, we meet many different kinds of ghosts, those that act as emotional suggestions of loss, who signal and alert us to the eroding presence of the unaddressed trauma of settler colonial violence. We also meet less ominous kinds of ghosts, those whom my research participants referred to as ancestral presences and sometimes, as 'a group of Aboriginal men.' These were welcome ghosts present in order to protect and watch over young Aboriginal children living in an institution for Aboriginal children. In relaying these ghost stories, it is not my intention to conflate such ghosts and stories 
of haunting-it is more to underline how ghosts are understood and used both in real and metaphorical terms by my research participants, who identify as members of the Stolen Generations, and finally, to conceptualise what that might mean for the ethnographic writing project. Such encounters with ghost stories have led me as an anthropologist to try to understand the relationship between ghosts and their witnesses, the structures through which such ghosts are experienced and indeed, the impact on those who are asked to bear further witness to them. It has also encouraged reflection on the role of such responses in the decolonising anthropology project.

The presence of sentient beings in the form of ancestors is well noted as a normative aspect of the everyday life experience and world-view of Indigenous communities (Read 2003). However, for my research participants, many of whom were removed from their Aboriginal families as babies and toddlers, such a way of being in the world is something that many have only come to understand as adults as and when they began the process of reconnecting with their Aboriginal identity and families. Contemporary Aboriginal communities often straddle two worlds (Ginsburg 2018), but Stolen Generations, removed from their families and communities, often find themselves caught between two worlds (Read 1999; Cowlishaw 2012), they are the doubly displaced of Indigenous Australians, and so too, it would appear, are their ghosts. The majority of my research participants who identify as Stolen Generations were removed from their Aboriginal families and communities as babies or toddlers in the 1940s/1950s, most spent their entire childhoods with one another in three particular institutions in New South Wales, others were adopted into white/non-Indigenous families $^{1}$. In the main, my research participant's contact with their Indigenous families and communities was quite minimal until they reached adulthood when they attempted to trace their families and communities. Reconnecting with family and community, 
however, is an ongoing challenge for many members of the Stolen Generations (Murphy 2011) and many never full reconnect with Aboriginal worlds. Much of this is reflected in my research participant's everyday (sometimes uneasy) unpicking of Aboriginal worldviews as adults, including how they themselves experience, view and interpret the ghostly.

Herein, I draw on the lens of Freud's uncanny (1919) to understand the complexities of the ghostly in the context of Stolen Generation's interpretation of their worlds and the impact of these engagements on the ethnographic project. For Freud (1919), the uncanny, 'unheimlich' is the defamiliarisation of the familiar through the return of something repressed at an individual or collective level. The notion of the 'uncanny' has a particular valence for Stolen Generations who move and have been moved between Indigenous and non-Indigenous worlds, and who, in their most ambiguous of political subjectivities, shift between different positionalities in their interpretation of their experiences of the uncanny. Like many kinds of ghost stories, Stolen Generation's ghost stories straddle the lines between reality and unreality, and Indigenous and nonIndigenous positions, in a way that shores up numerous ethico-political dilemmas.

Such encounters with the ghosts and ghost stories of our research participants begets, therefore, the question of how we as anthropologists should confront, negotiate and deal with the 'really real' (Geertz 1973: 112) ghostly encounters of some of our research participants. This article opens with a reflection, in fact a ghost story, from a tattered field-note book crammed with many such stories. This particular ghost story tells of childhood imaginings of ghostly hauntings, and I relay it to highlight the intimate and complex relationship that my research participants have with their personal traumas, the haunting and cyclical character of traumatic experience, and the adversity of loss but also the force of certain continuities. Herein, I also relay other 
stories about ancestral presences in order to think through the challenge of the ethnographic and writing encounter with other people's ghosts, particularly given that for many of my research participants these ghosts are very real presences in their lives. As 'merchants of astonishment' (Geertz 1984: 275), ghost-hunting anthropologists face innumerable challenges in their research and writing. That we can imagine having a relationship with such ghosts, even that they seem to exist as part of a different and more flexible ontology, is what makes their presence and subsequent analysis all the more challenging.

In Nietzche's famous aphorism on the abyss, he warned that 'he who fights with monsters should be careful lest he thereby becomes a monster. And if thou gaze long into an abyss, the abyss will also gaze into thee' (Nietzsche 1844-1900). What is terrifying about engaging such ghosts is that it is akin to staring into Nietzche's abyss, indeed, such entities seemingly have their own agency and unpredictability in their speaking of and to Stolen Generations and Aboriginal ways of being in the world or the ongoing traumas of the settler-colonial encounter. Stolen Generation's ghosts and their subsequent analysis thus bring uncomfortable truths and public secrets, a folding hall of mirrors; it is this predicament that we must manage in our ethnographies of the uncanny in putative postcolonial settings.

\section{Spectral Contexts: Australia's Stolen Generations}

After years of societal silence on the issue of Australian Aboriginal child removal, a commission of inquiry was conducted, resulting in the Australian Human rights and Equal Opportunity Commission (HREOC) tabling one of the most shocking and painful reports that Australia had ever seen on May 26th, 1997. The Bringing Them Home 
(1997) report was the result of months of consultations right across the continent of Australia. It established that between the years of 1910 until the late 1970s, between one in three and one in ten Indigenous children, were forcibly removed from their families. The Commission listened to 535 stories of removal, abuse, loss, and continuing pain and trauma, and had access to nearly a thousand more in written form. Intense debate followed the tabling of the report about the nature of the removals, the policies and historical motivations of those involved in the removals, as well as the language deployed by the report to describe the widespread removal of mixed heritage Aboriginal children (as cultural genocide or ethnocide) (see Haebich 2000; Manne 2001; Moses 2004; Read 1996;1999;2003).

Coming to the field a number of years after the tabling of the report meant arriving into a context radicalized through activism, campaigning, the discourse of reconciliation, and human rights, and a deep desire for reparation and healing. I conducted fieldwork for a period of two years (2003-2005), with a number of repeat field visits in 2009 and 2016. Fieldwork was mainly conducted through an organization (now defunct) called the National Sorry Day Organisation and a number of local reconciliation groups. While I was based in New South Wales, I also travelled to Queensland, South Australia, Victoria, ACT, and Central Australia to interview and track a number of different memorial projects as well as to attend various Stolen Generations' events, commemorations, conferences, and reunions. My research was conducted at a time of dramatic change for members of the Stolen Generations, where the Bringing Them Home report made possible the public speaking out of the personal pain of removal. Fuelled by questions about the meaning and value of the past for all members of society, Australians were beginning to engage with the politics of pain in a way that engendered a frank consideration of justice, truth, and reparations. 
My field-site therefore was one where reunions to the sites of former institutions, memorial projects, reparations campaigns, demands for an apology (Murphy 2009), and attempts to re-unite with culture, language and kin were all modalities of seeking healing and legitimization (Murphy 2017). The reconciliation process in Australia also created a space where Stolen Generations began to return to the sites of former institutions (Murphy 2011). I attended a number of these reunions and they were important emotional and ethnographic encounters with both my research participants and the larger politics of the field. Going on these trips and to various events with members of the Stolen Generations provided occasions to listen to many stories about the experience of being removed and institutionalized or adopted. Stories of forcible removal, stories of institutionalization, stories of abuse, of the ineffability of loss (but also many stories of hope, of moving forward) became core and pivotal to my research journey (Murphy 2015).

Many of these stories, in particular, the very many ghost stories that my research participants shared with me, brought us (in our research encounter) to a very particular kind of threshold space, wherein the boundaries between reality and the unknown (or the phenomenal and the noumenal) were blurred, perhaps the kind of 'intersubjective in-between' of which Michael Jackson (2013: 11) writes. It is in this 'in-betweeness' of the ethnographic encounter that the unwieldiness, even slipperiness of the ghost becomes most apparent, in both its realness to my research participants, and in its potency as an interpretational form for understanding the impact of settler colonial violence. This is what makes any interpretation of the story of the hand so challenging. The story was told slowly, reluctantly at first. Standing with the women by an empty space with one lady outlining the structure of the dormitory, one of my closest research participants said 'oh tell her the story of the hand'. The lady was quickly silenced. En 
masse, we continued to the kitchen where the owners of the bible college had prepared food and drink for us. Sitting in the sunshine on a small hill to the back of the institution, I was slowly invited into the circle of women and their stories of haunting began. Such stories persist in my reflections and writings. Indeed, Avery Gordon (2011:1) tells us that ghosts insist on 'something-to- be- done'; in our encounters with them they mobilise us to look at the world of our research participants from very different angles. In terms of what they evoke, they also encourage a project of ethnographic response as political critique (Biehl and MacKay 2012).

There is, of course, also a futurity to ghosts; some ask us to pay heed to how the absences and losses of past will unravel the lifeworlds of subsequent generations. This is visible most critically in the context of this work with the increased rate of removal of Aboriginal children in contemporary Australia, now dubbed the new Stolen Generations. Indeed, Derrida (1994) reminds us of this generational trajectory by telling us that every ghost is haunted by ghosts of its own, and the stories herein highlight how survivors of trauma inhabit a shadowy world not of their own making, where the telling and retelling of ghost stories becomes a way of negotiating, and sometimes even reconciling with trauma and suffering. More specifically, in the context of 'postcolonial' understandings of the ghost, Indigenous categories of the spirit or ancestor world are often conflated or intermeshed with western constructions of the ghost and haunting (Read 2003; Gelder and Jacobs 1998). The question remains, however, for this anthropologist of what kinds of truths my research participants were hoping that I would glean from such stories. What, ultimately, was the purpose of this intimate sharing?

\section{Reading the Ghostly}


Ghosts and ghost stories have long been part of what Boyd and Thrush (2011: ix) call a 'colonial fantasy.' However, ghost stories told by members of the Stolen Generations have received scant attention in the wider literature on the relationship between haunting, ghosts, and colonialism (see Peter Read 2003). The ghost stories I was told during my fieldwork were masterpieces of loss and longing calling for the witness to engage in an act of imaginative sympathy and ultimately, a kind of ethico-political response. Stephen Muecke (2016) in his work on fictocriticism remarks that 'encounters with alterity can be like engines for the production of concepts' (Muecke 2016: xv). Indeed, the notion of ghosts and haunting proves Muecke's point; ghosts exist or are called upon in order to negotiate, understand, maybe even validate when there is a surplus of trauma, suffering and memory.

Ghosts are undoubtedly widely conceptualised in academic literature with Freud's (1919) sense of the uncanny and Derrida's (1997) provocative 'hauntology' featuring large. The literature on ghosts has tended to be dominated in recent years by Derrida's concept of hauntology, which inspired the so called 'spectral turn,' as well as Avery Gordon's (1997) important work Ghostly Matters. Much of the literature tends to see ghosts as indexical of collective trauma(Bear 2008; Carsten [ed.] 2008;Feuchtwang 2009 \& 2010; Kwon 2008; Mueggler 2001) others seek to examine the context of culture, cognition and language (Delaplace 2009; Déléage 2007; Taylor 1993; Pons 2002). Fewer studies, however, attempt to grapple with the ghost as a real, haunting entity, with the exception, in particular, of work by Paul Stoller (2014) and others (Sconce 2000; Chéroux 2004). A large body of work exists which examines ghosts as concrete manifestations of traumatic memory (see Bear 2008; Carsten [ed.] 2008; Feuchtwang 2009 \& 2010; Kwon 2008; Mueggler 2001). Ghosts then serve a variety of purposes; therapeutic, performative, and political (to name but a few), and their 
importance for those who encounter them in the ethnographic process should not be understated (Stoller 2014).

However, many of these approaches are not without their critics. Dylan Trigg (2012), writing about memory and place, critiques the widespread social constructivist approach and metaphorical usage of hauntology and ghosts in the social science literature. Trigg subsequently asks the important question of how scholars should deal with the 'ghost as ghost' (2012:287). He says:

Rather our treatment of the ghost as a ghost means that we wish to remain open to the experiencing of a ghost as just that - a lived experience that assigns a supernatural category to natural phenomena (2012: 287).

Heavily critical, therefore, of the use of the ghost as a second order or metaphorical concept deployed to the service of understanding the ghost as a symptom of something other (2012: 286); Trigg, instead, suggests a phenomenological approach to understanding the experience of being haunted. He argues that this approach should be constituted by conferring a reality upon the ghost and remaining open to its existence as a supernatural category while suspending all desires to treat the ghost as symptomatic of other things--rather than an entity in and of itself (2012: 287). For Trigg, understanding the ghost as ghost, means not succumbing to ideological or aesthetic interpretations or usages of the ghost--but rather in a suspension of theory--he argues that we must confront the ghost in its 'thingness,' in order to give it voice. Trigg's work does not invalidate the use of the ghost in an interpretive or constructivist fashion --but it asks us to recognise the ghost in its experiential fullness-- in its 'agential realism' (Barad 1999:7). ${ }^{2}$

Such an approach exists as an important counterpoint to the widespread social constructivist means of engaging with ghosts. But as Peter Read (2003), the Australian historian much celebrated for his work with members of the Stolen Generations points 
out, work with ghosts can sometimes be seen as outlandish, beyond the remit of the scholarly scholar. It is here that that I circle back to the importance that the aesthetic frame of the uncanny holds in furthering our understandings of how some members of the Stolen Generations draw on their ghosts to articulate their experiences in the world. If the uncanny is 'associated with an experience of the threshold, liminality, margins, borders' (Royle 2003:vii) then it provides a particularly apposite lens through which to think through the ghost stories my research participants shared with me. In his 1919 essay, Freud constructs the uncanny thus:

An uncanny effect is often and easily produced by effacing the distinction between imagination and reality, such as when something that we have hitherto regarded as imaginary appears before us in reality, or when a symbol takes over the full functions and significance of the thing it symbolizes, and so on. (Freud 1919: 15)

For Freud, the uncanny or unheimlich derives from the concept unhomely, something which should have remained secret but has somehow been revealed-the familiar made strange in many ways. He explains that the word heimlich means home, intimate, familiar, or indeed, something that is kept at home-secretive and hidden. It is at this point, that the notion of 'heimlich' coincides with its opposite, 'unheimlich,' meaning unhomely, uneasy or eerie-the return of the repressed. Many of my research participants who feel caught between Indigenous and non-Indigenous worlds inhabit what Rebecca Byrant (2016: 1) has called an 'uncanny present' which she describes as 'moments when the present (...) becomes anxiously visceral to us as a moment caught between past and future.' It is in and through this 'uncanny present' that some of my research participant's ghost stories emerge to illuminate the challenge of lives lived liminally.

Documenting the uncanny in a context such as Australia is thus key to advancing our understandings of often challenging decolonisation processes. Ken Gelder and Jane Jacobs in their book Uncanny Australia: Sacredness and Identity in a Postcolonial 
Nation (1998) highlight how the removal and destruction of Indigenous Australians was foundational to the creation of the Australian nation-state; the granting of land rights and the reconciliation movement served therefore as an unsettling reminder of how Australia was founded for many non-Indigenous Australians. Land rights operate thus as a kind of uncanny by defamiliarising home, place and nation-state. Faye Ginsburg (2018) conceptualises this even further in relation to Indigenous Australians as the 'Indigenous uncanny' which she posits as the distinctive ways Indigenous Australians connect to the uncanny both through a mode of relating to ancestral presences as well as an understanding of how the colonial past haunts and disrupts contemporary Indigenous lifeworlds. The story of the hand and the ancestors (and indeed, other ghost stories which I heard) have the possibility to operate at both of these levels; my research participants knew this too, living with and evoking the uncanny happened in many different ways and for different ends; sometimes therapeutic, sometimes political. There were, and continue to be, many reasons for their telling.

\section{The Story of the Hand and the Ethnographer's Dilemma}

I was stolen from my family, my country -I lost everything, everything stolen from me and now only suffering. I tried to get back home, to meet my family-reconnect- my counsellor called it, but they didn't want to know me. Only ghosts from my childhooda world I can never know.

Amy, Stolen Generation.

The women guided me around the former Aboriginal children's institution as we visited together. Every so often, here and there, they beckoned to tell me a story from their childhood. We walked together sometimes in silence, sometimes to the click train of a relative's camera, often in tears, and occasionally in laughter. Fragments of stories were told; here, a punishment took place; there, some other little girl reminded them on a bad day that they did indeed have a family somewhere out there. As we stood together, 
outside in what was once a play-yard, Emily one of my closest research participants, told me that some-how she just somehow knew (tacitly) 'Aboriginal ways' as a young girl. She told me that she knew what local plants were medicinal, even though she had been removed from her family as a baby. Emily evoked her story in the form of a mystic connection to her Aboriginal identity and culture. She suggested that the spirit ancestors were there to guide her as she struggled with life as a member of the Stolen Generations, but that she only realised this much later as an adult. Emily was one of the women who did not want to repeat the story of the hand, she cried as it was told.

Stories of all kind filled our afternoon at the former institution for Aboriginal girls that day we visited together--some were putrid and harsh, others warm and loving. Some were memories, some were ghost stories. Some of these ghost stories were told to amuse, some to remember and teach and others to frighten; some were told with precipitous eloquence, others in half muted tones. While such stories informed many of my encounters and understandings of how these members of the Stolen Generations were making sense of the experience of removal, it took some time for me to fully engage with these stories as a form of sense-making about a traumatic past whether as an unwelcome, painful reminder or as value laden tools of resistance and empowerment, as well as a political statement about identity and belonging.

McEwan (2007:28) tells us that ghost stories and hauntings exist in the 'interstices of social forces and lived experience; ghost stories, both oral and written, proliferate at times of social upheaval, where ghosts symbolise the fracturing of time and a disquieting present.' In Australia, the ghost stories I was told by members of the Stolen Generations exist within these interstices. However, such stories present a particular dilemma for the ethnographer attempting to understand their telling, retelling, performance and ultimately, their meaning. While comfortable with my research 
participant's belief in ghosts, I was, nonetheless, confronted by such stories given their potentially ominous interpretations, and the women's initial reluctance to openly tell the story of the hand. This story stays with me; even years later, I often reflect on what the women were trying to tell me. In creatively drawing me into the disquieting world of ghost stories, the women left me with a sense that their childhood was one enmeshed with the constant threat of loss and abuse. It also posed bigger issues for the ethnographer trying to make sense of the role of ghosts in understanding the women's experiences of trauma and suffering. There is thus a critical ethico-political imperative for the ethnographer in bearing witness to these Stolen Generation's narratives of haunting, which is the need to give these ghosts 'a hospitable memory(...) out of a concern for justice' (Labanyi 2002: 12). In the context of the Stolen Generations, this concern for justice is anchored in the thematics of resistance, reconciliation (apology, reparation) and reconnection to kin, country and culture. Ghost stories such as the story of the hand thus open critical gaps which are both modes of speaking to as well as calls for action.

The story of the hand also signals something much more distressing for me. But how should it be interpreted-if at all? Instinctively and in the moment, I first bore witness to this story, it immediately conjured an image of the abuse so commonplace in many of the institutions for Aboriginal children. In listening to its first telling, I no longer saw the elderly women I was with, but frightened little girls alone, night after night, subjected to loneliness and fear. Little girls missing their families, unsure of the future, never feeling safe, as little children should. Perhaps, I wondered, if it was the only way that a group of women sitting on a hill behind the institution could (many years later) communicate it to one another and finally, to me. 
While it is not my intention to reduce the hand to a mere metaphor and thus do a kind of violence to this story, I do want to use it as way of thinking about the kinds of spaces that the telling (and retelling) of these ghost stories open onto. The ghost stories appeared to be central in some of the women's re-imagining of the institution, perhaps a way of articulating a terrible past. The complexities of living life in an 'unhomely' home, an institution for Aboriginal children, is evoked through the violence of the story of the hand, yet for many of my research participants this is the only home they can remember or identify with. In returning to their Aboriginal families and hence, home, many of the women from this institution found themselves despondent, not feeling at all 'at home,' rather, feeling out of place, once again displaced and unfamiliar. The women's relationship with the uncanny in the form of these ghost stories therefore articulates the 'in-between-ness' that many of my research participants continue to feel as lives lived in an 'uncanny present' (Byrant 2016). In some ways, these ghost stories can be recast as a way of gaining rhetorical power in their inscription of a rather potent kind of circularity between feelings of emplacement and displacement in their trajectories of belonging and home-seeking. So too, can the other stories I was told about the watchful presence of Aboriginal ancestors standing near a rusting outdoor toilet at this institution.

\section{Recalling the Ancestral Revenants: The Time is out of joint}

The stories of hauntings continue. One of the other girls chimes in with her memories of the ancestors. "We did not even know we were Aboriginal," she tells us. "But yet somehow we were not afraid of the group of Aboriginal men who used to watch over us. If we needed to go to the bathroom in the middle of the night, we had to go outside. They would be there, waiting beside the cramped and rusted dunny. They were traditional Aborigines, dressed in old style clothing, with big long spears. I 
know now that they were the ancestors. They were there to protect us, even though we did not know we were Aboriginal. And protect us they did, nothing bad ever happened to us on our way outside on those dark nights."

\section{Fieldnotes 2003}

Sharing some salty chicken sandwiches and a hot pot of steaming tea during Michael's lunch break, he tells me that he continues to be haunted by the ghosts of his past. I hesitate, I have gotten used to hearing tales of ghosts and hauntings over the course of my fieldwork. He smiles and adds that he is not crazy, Aboriginal people have a way with these things, "when I was a child I used to see my ancestors standing around the home painted in bright vibrant colours and holding spears".

\section{Fieldnotes 2004}

Stories about Aboriginal Ancestors watching over members of the Stolen Generations were relayed with similar frequency to the story of the hand. While the story of the hand was a particularly sinister one and remained for the most part 'un-interpreted' by the women, this was not always the case in the context of stories about the ancestors. Both kinds of stories recapitulate tropes of loss and trauma, and point to the complexities of living life in an un-homely home re-producing thereby the uncanny sense of alienation that my research participants feel from both Indigenous and nonIndigenous worlds, an alienation which to do some degree keeps them located in an 'uncanny present.'

Invoking the ancestors assumed many forms in differing locations. On one return car journey from Canberra to Sydney with some of my research participants, we began to discuss these stories of the ancestors. I was told of a photograph that was taken of them when they were young, in which the young girls spied an Aboriginal family sitting in the tree above their heads. When I asked of the photos' whereabouts, I was told that they never acquired possession of it, and I left it at that. Stories about the ancestors were told with gravity and respect, a tone very different to that of the story of the hand. Indeed, I never doubted in my research participants' firm belief that they had witnessed the watchful presences of their ancestors. Akin to Laura Bear's (2008) Anglo-Indian research participants who also spoke of welcome ghosts, my research participants 
connected these visitations to their identity, culture and history as Indigenous Australians; as children they understood these presences as watchful, protective elderly men, as adults they began to understand them as ancestors. This is especially poignant given how much loss members of the Stolen Generations have undergone with respect to their culture and traditions. Evoking these spectral ancestries seemed then, at least for this group of Stolen Generations, to be a claim for an embedded genealogy, a repositioning and reclaiming of identity and belonging in Indigenous worlds.

Historical, postcolonial traumas such as Aboriginal child removal fuel a form of cultural bereavement which leads to alternative modalities of expressing loss and suffering. Avery Gordon reminds us that a 'ghost is primarily a symptom of what is missing,' representative of a loss of life or equally of a path not taken, what Gordon further characterizes as 'furniture without memories' (1997:4). Both the story of the hand and the many stories I heard about ancestral presences can be 'read' in this way. Both stories firmly demarcate the spaces of absence which mark the lives of many of the Stolen Generations whom I met. As many members of the Stolen Generations feel apart from the Indigenous cultures that they have been removed from, attempting to reconnect with their Aboriginal family and communities, relearn lost attachments, language and cultural ways is a key trope in their healing narratives (see Read 1996; Murphy 2011). Recalling ancestral figures standing on a hill behind an institution for Aboriginal children is the kind of uncanny that opens up a space where as Laura Bear (2008: 58) tells us 'an authenticity of history, family, and community' is produced and felt because of the permeability of temporal flows wherein 'the past and spaces are felt to act on you from the outside.' The story of the ancestors ultimately offers a kind of at-homeness through the uncanny otherwise unavailable to many of my research participants. 
Like the story of the hand, the stories of ancestors can also be seen as a political expression of loss and trauma ${ }^{3}$, thereby fulfilling a number of roles: resistance, identity making, metaphor and meaning-making. The interpretive plurality of these ancestral presences is thus equally as complex as the story of the hand. One of my research participants puts it thus:

You see I think they came here to look after us at night. They guarded over us and watched us. We might have been forced out of our culture-but the ancestors never forgot us. They are always there.

The tales of the ancestors and the story of the hand exist in a neat juxtaposition, but both stories shore up the sense of separation and loss that members of the Stolen Generations feel. The story of the ancestors, however, reconfigures their sense of belonging to a group of people they felt both attached to and apart from. They are in the same moment a reflection of one's identity and what one has indeed lost-thus emphasizing the uncanny experience of a threshold or liminal every-day. Ultimately though, the watchful presences of the ancestors and their recalling signified that in spite of being removed from kith and kin, members of the Stolen Generations still had a right to belong and a place to belong to. These ancestral presences are ghosts which help to reclaim and possibly, even heal.

\section{The Spectre at the Feast: In Defence of the 'Really Real'}

Ghosts are everywhere. Ghost is a concept for which there is no referent, no evidence, anywhere, any place, any time in the entire sweep of human experience, yet one that is vital in many cultures and perhaps in every culture since the Upper Paleolithic Age. Apparently, there is a powerful impulse within human imagination that flows inevitably to this unwarranted fiction. (Mark Turner 2004)

The ghostly tale of the hand renders the experience of Aboriginal child removal political and ghastly in the same moment. The story of the ancestors brings another 
kind of presence to my research participant's engagement with the uncanny. In the absence of a critical language to evoke the workings of power, the tale of the hand and the stories of the ancestors and their analytical interpretation requires in Frazer's terms a kind of 'sympathetic magic' that allows us to shift between the world as analyst and the world made through 'hauntings, ghosts and gabs, seething absences, and muted presences' (Gordon 1997: 21). In short, they encourage us also to consider the ghost as really real. The hand in its liminality, the ancestors in their watchful presence, all in their comings and goings into and out of the world of the young girls and their memory in later life, signals lifeworlds burdened with concerns for tradition, truth, memory, and of course, recovery. It moves us as witnesses between the real and the surreal thereby engendering more questions than answers. To whom did this hand belong? Why did it come to the institution night after night? Did it harm the little girls? Is the hand a ghostly metaphor or a real encounter with a ghost? Why were the ancestors present at the institution? Why were these girls, so disconnected from Aboriginal worlds, so comforted by the presence of these ancestral figures?

Any attempt to answer such questions evinces that ghosts, above all else, are anamorphic; their potency lying in their ability to translate, reinterpret, and reiterate how the past is perceived and used. Whether real or imagined, ghosts have the potency to affirm at least the continuity of life in the face of adversity; the fantasy of limitlessness in the face of lives lived within limits. One of the lingering questions from these encounters with my research participant's ghosts and ghost stories is does this experience present a challenge to ethnographic authenticity or even, tell-ability? Having presented some of these ghost stories and ethnographic encounters with Stolen Generations at academic conferences, I am well aware of how ghosts are perceived in such contexts. But the challenge is, ultimately, in attempting to understand what it is 
our research participants are doing when they share what are sometimes very intimate encounters with the uncanny. Ultimately, we need, as Nyce, Talja, and Dekkerall tell us in their conceptualisation of ghosts in the ethnographic project, to do as all good ethnographers should and:

turn the mirror back on ourselves and address not only the question of who holds the pen but what ontology are we committed to and what consequences this has for the kind of ethnography we wish to do (2015: 92)

Indeed, through this process, it is clear that testimony of or bearing witness to a traumatic past and the ghost story mutually implicate each other-both involve the acknowledgement of a difficult reality-one that outstrips our words to encompass what has happened-by a powerful figure that is present to the telling (the State and the ghost respectively). A sensory ethnography of the uncanny, however, can engage such challenges.

Much scholarly writing on ghosts is conducted by those who 'proceed as though both our readers and our informants must equally subscribe to the logic that things like ghosts and witches do not really exist' ( Nyce et al. 2015: 84). In so doing, we inflict an epistemic violence on our research participants, absenting and silencing them (and indeed, their ghosts) on a number of levels. Insofar as we as anthropologists try to compose the lives of others through our writing, even given that we and our participants live lives beyond any final telling, we cannot always do justice to their full humanity and range of encounters. Gelder and Jacobs (1998) remind us that ghost stories typically tell of tales of possession, of being possessed or possessing haunted things, but they argue that 'the postcolonial ghost story speaks more directly about (dis)possession through its emphasis on visiting or on passing through' (Gelder and Jacobs 1998: 188). This passing through, as the story of the hand and the watchful ancestral presences show 
us, is one of negotiation and recognition for both my research participants and I, as ethnographer.

Perhaps it is here that understandings of the ghost as real and the ghost as metaphor might meet, a nexus point of symbolism, imagination, and partiality; Mark Turner's (2004) 'unwarranted fiction' from the opening epigraph to this section. The story of the hand and the ancestors demands a more sensory ethnography of the uncanny (Pink 2015) thus becoming part of a burgeoning decolonial anthropology (Allen 2016). This ultimately could form part of what Julia Emberley (2015) in her work on the testimonial uncanny calls 'a reparative episteme,' which alongside Indigenous testimonial practices would facilitate an incorporation of 'a multiplicity of ways of knowing that advance our critical understanding of the contemporary complexities of decolonization' (Emberley 2015: x). Moving towards this kind of sensory ethnography of the uncanny means repopulating our writings with our research participants ghosts' in ways that create the potential for them to become the 'alternative figures of thought' that (Biehl and McKay 2012: 1212) posit as necessary to give ethnography and anthropology more power as a form of political critique. Attending to the uncanny in this way, by embracing the fragments, splinters, and the ' precarious yet creative worldmaking' of our research participants can and should make 'politics matter differently'(Biehl and McKay 2012: 1212) through a more profound understanding of how social suffering manifests. In the particular context of my work with members of the Stolen Generations, recognising the force of the uncanny in their lives, allows not only for more analytical and conceptual elaborations of their lifeworlds but connects to deeper understandings of the intergenerational impact of trauma, identity politics, and reconciliatory and reparative movements. An ethnography of the uncanny in the context of Stolen Generation's experiences thereby has the potential, following Michael 
Jackson (2012: 222), to speak to a politics of justice rather than pity; one which might, through near readings of ghost stories (as told, not as genre per se), have the power to suspend universal moral judgement-ultimately, bringing responsiveness to the responsibility of witnessing (2012:225) thereby engendering necessary and urgent ethico-political responses.

The motif of ghosts, then, is a frequently recurring one that informs our sense of how trauma impacts on and shapes the lives of survivors. Beginning a conversation with these ghosts is the beginning of a dialogue with truth, responsibility, and acknowledgement. For my research participants, moving through the storied archive of their lives, a repository of ghosts and haunting tales, and across the nascent landscape of home and 'Aboriginal' country, meant a confrontation with the past and the different kinds of ghosts embedded therein. In conversing with divergent emanations of the uncanny, even in their inhabiting of an 'uncanny present' (Bryant 2016), many of my research participants traced a trajectory of haunting which led them to a space where they could begin to finally speak publicly about their experiences. That is, ultimately, the power of confronting ghosts.

\section{References}

Allen, J.S and Jobson, C. 2016 The Decolonizing Generation: (Race and) Theory in Anthropology since the Eighties, Current Anthropology 57:(2): 129-148.

Barad, K. 1999 Agential realism: Feminist interventions in understanding scientific practices, in (ed.) M. Biagioli The Science Studies Reader. New York, New York: Routledge, pp. 1-11.

Bear, L. 2008 Ruins and ghosts : The domestic uncanny and the materialization of Anglo Indian genealogies in Kharagpur, in (ed.) J. Carsten Ghosts of Memory. Oxford: Blackwell, pp. 36-57.

Berlant, L. 1997 The Queen of America goes to Washington city: Essays on Sex and Citizenship. Durham, NC: Duke University Press. 
Bhahbha, Homi K. 1994 The Location of Culture. London; New York: Routledge.

Biehl, J. and R. MacKay. 2012 Anthropology as political critique, Anthropological Quarterly 85 (4): 1211-1230.

Boss, P. 1999 Ambiguous Loss: Learning to Live with Unresolved Grief. Cambridge, Mass.; London: Harvard University Press.

Boyd, C. and A. Thrush. 2011 (eds.) Phantom Past, Indigenous Presence: Native Ghosts in North American Culture and History. Lincoln: University of Nebraska Press.

Buse, P. and A. Stott. 1999 (eds.) Ghosts: Deconstruction, Psychoanalysis, History. Basingstoke and London: Macmillan.

Butler, J. 2004 Precarious Life. The Powers of Mourning and Violence. London/New York :Verso.

Bryant, R. 2016 On critical times: return, repetition, and the uncanny present, History and Anthropology, 27 (1): 19-31.

Caciola, N. 2000 Spirits seeking bodies : death, possession and communal memory in the Middle Ages, in (eds) B. Gordon and P. Marshall The Place of the Dead. Cambridge : CUP, pp. 66- 86.

Carsten, J. 2008 (ed.) Ghosts of Memory. Essays on Remembrance and Relatedness. Oxford: Blackwell.

Cowlishaw, G. 2012 Culture and the absurd: the means and meanings of Aboriginal identity in the time of cultural revivalism, Journal of the Royal Anthropological Institute 18(2): 397-417.

Chéroux, C. and A. Fischer 2004 (eds) Le troisième oil : La photographie et l'occulte. Paris: Gallimard.

Delaplace, G. 2009 L'invention des morts. Sépultures, fantômes et photographie en Mongolie contemporaine. Paris :EMSCAT (Nord-Asie 1).

Déléage, P. 2007 Trois points de vue sur les revenants sharanahua , L'Homme 183 : 117- 146.

Derrida, J. 1994 Specters of Marx: The State of the Debt, The Work of Mourning, and the New International. New York: London: Routledge.

Emberley, J. 2014 The Testimonial Uncanny: Indigenous Storytelling, Knowledge and Reparative Practice. Albany, NY: SUNY Press.

Feuchtwang, S. 2009 The transmission of traumatic loss: a case study from Taiwan, in (eds.) N. Argenti and K. Schramm Remembering Violence. London : Berghahn Books, pp. 229-250.

Feuchtwang, S. 2010 The Anthropology of Religion, Charisma and Ghosts. Chinese Lessons for Adequate Theory. Berlin : Walter de Gruyter.

Freud, S. 1919 The Uncanny, in (ed. and trans.) Strachey, J. The Standard Edition of the Complete Psychological Works of Sigmund Freud Vol. XVII. London: Hogarth, pp. 219-252.

Gelder, K. D. and J. M. Jacobs. 1998 The postcolonial uncanny: On reconciliation, (Dis)possesion and ghost stories, in (eds.) K. D. Gelder \& J. M Jacobs Uncanny Australia: Sacredness and Identity in a Postcolonial Nation. Carlton, Vic.:

Melbourne University Publishing, pp. 23-42.

Geertz, C. 1973 The Interpretation of Cultures : Selected Essays. New York :Basic Books.

1984 Anti-Anti-Relativism, American Anthropologist 86 (2) :263-278.

Gigliotti, S. 2003 Unspeakable pasts as limit events: The Holocaust genocide and the Stolen Generations, Australian Journal of Politics and History 49 (2):164-181. 
Ginsburg, F. 2018 The Indigenous uncanny: Accounting for ghosts in recent Indigenous Australian experimental media, Visual Anthropology Review 34 (1):6776.

Gordon, A. 1997 Ghostly Matters: Haunting and the Sociological Imagination. Minneapolis: University of Minnesota Press.

2011 Some thoughts on haunting and futurity, Borderlands 10 (2): 121.

Gordon, B. 2000 Malevolent ghosts and ministering angels: apparitions and pastoral care in the Swiss Reformation, in (eds.) B. Gordon and P. Marshall The Place of the Dead. Cambridge: CUP, pp. 87-109.

Haebich, A. 2000 Broken Circles: Fragmenting Indigenous Families 1800-2000. Fremantle, W.A.: Fremantle Arts Centre Press

Jackson, M. 2013 The Politics of Storytelling: Variations on a Theme by Hannah Arendt. USA: Museum Tusculanum Press.

2012 Lifeworlds: Essays in Existential Anthropology. Chicago: University of Chicago Press.

Kwon, H. 2008 Ghosts of War in Vietnam. Cambridge: Cambridge University Press.

Labanyi, J. 2002 (ed.) Introduction: Engaging with ghosts; or, theorizing culture in modern Spain, in (ed.) J. Labanyi Constructing Identity in Contemporary Spain: Theoretical Culture in Modern Spain. Oxford: Oxford UP, pp.1-14.

Marshall, P. 2007 Mother Leakey and the Bishop. A Ghost Story. Oxford: Oxford University Press.

Manne, R. 2001 In Denial: The Stolen Generations and the Right. Melbourne, Vic.: Black Inc.

McEwan, C. 2007 A very modern ghost : postcolonialism and the politics of enchantment, Environment and planning D : society and space 26 (1): 29-46.

Moses, D. 2004 Genocide and settler society in Australian history, in (ed.) A. Dirk Moses Genocide and Settler Society. NY: Berghahn Books, pp 3-49.

Muecke, S. 2016 The Mother's Day Protest and Other Fictocritical Essays. London: Rowman \& Littlefield International.

Mueggler, E. 2001 The Age of Wild Ghosts. Memory, Violence, and Place in Southwest China. Berkeley: University of California Press.

Murphy, F. 2009 We took the children from their mothers: A reflection on the politics of apology, recognition and respect in an Australian context, Irish Journal of Anthropology 12(2) :56-62.

.2011 Archives of sorrow: An exploration of Australia's stolen generations and their journey into the past, History and Anthropology 22 (4): 481495

2012 The House on the Hill: An analysis of Australia's Stolen Generations' journey into healing through the site of trauma, in (ed.) J. Skinner Writing the Dark Side of Travel. New York:Berghahn, pp. 163-184.

.2015 In dreams begin responsibilities:the ethics of researching and writing trauma, Civilisations, Special Edition, Fieldwork in Difficult Contexts 64 :91-101. .2017 Memorialising the story of Australian Aboriginal child removal: The story of reconciliation place, in (eds.) Larkan F. and F. Murphy Memory and Recovery in Times of Crisis. UK: Routledge, pp.32-45.

Nietzsche, F. W. 1844-1900. Beyond Good and Evil : Prelude to a Philosophy of the Future. London, England; New York, New York, USA :Penguin Books, 1990. Print. 
Nyce, J. M., Talja, S., Dekker, S. W. A., 2015 When ghosts can talk: Informant reality and ethnographic policy, Journal of Ethnology and Folkloristics 9(1): 81-98.

Pink, S 2015 Doing sensory ethnography - Second Edition. London, United Kingdom: Sage.

Pons, C. 2002 Le spectre et le voyant. Les échanges entre morts et vivants en Islande. Paris: Presses de l'Université Paris Sorbonne.

Read, P. 1996 Returning to Nothing: The Meaning of Lost Places. New York: Cambridge University Press. 1999 A Rape of the Soul So Profound: The Return of the Stolen

Generations. St. Leonards, NSW, Australia: Allen \& Unwin.

2003 Haunted Earth. NSW: UNSW Press.

Royale, N. 2003 The Uncanny. UK: Routledge.

Stoller, P. 2013 Yaya's story: The Quest for Wellbeing in the World. Chicago: The University of Chicago Press.

Turner, M. 2004 (ed.) The Ghost of Anyone's Father, Shakespearean International Yearbook Vol 4. U.K.: Ashgate, pp. 72-97.

Schmitt, J. 1994 Les revenants. Les vivants et les morts dans la société médiévale. Paris: Gallimard.

Sconce, J. 2000 Haunted Media : Electronic Presence from Telegraphy to Television. Durham : Duke University Press.

Taussig, M. 2013 I Swear I Saw This: Drawings in Fieldwork Notebooks, Namely My Own. Chicago: University of Chicago Press.

Trigg, D. 2012 The Memory of Place: A Phenomenology of the Uncanny (Series in Continental Thought: Volume 41.). Athens: Ohio University Press.

Whitlock, G. 2001 In the second person: Narrative transactions in Stolen generations testimony, Biography 21 (1):197-217.

Wilson, R. and M. Dodson 1997 Bringing Them Home: Report of the National Inquiry into the Separation of Aboriginal and Torres Strait Islander Children from their Families. Sydney: Human Rights and Equal Opportunity Commission.

Wolfreys, J. 2002 Victorian Hauntings: Spectrality, the Uncanny and Literature. Basingstoke: Palgrave Press.

\footnotetext{
1 Individuals who identify as members of the Stolen Generations often have quite diverse experiences of removal, institutionalization or adoption, and indeed, reintegration into their families depending on when/how they were removed and where they were removed to, and indeed at what time period during the history of removal. It is not my intention to homogenize or conflate different personal narratives or histories in the writing of this piece. However, the group of people I conducted my research with, had very similar experiences in three particular institutions, much of this piece is constructed around their experiences of these institutions.

2 "If our descriptive characterizations do not refer to properties of abstract objects or observation-independent beings but rather describe agential reality, then what is being described by our theories is not nature itself but our participation within nature" (Barad 1999:7).

${ }^{3}$ By way of note, I do not intend here to conflate the different kinds of presences which Stolen Generations spoke to me about, some, as I have suggested, are material presences linked to ancestors, others are examples of unaddressed trauma.
} 